\title{
ІНТЕГРОВАНИЙ ПНДХІД ДО ЗАПОБІГАННЯ НАСИЛЬНИЦЬКИМ ЗЛОЧИНАМ
}

\begin{abstract}
СВДОКІМЕНКО Світлана Вікторівна - доктор юридичних наук, доцент, завідувач відділу підвищення кваліфікації Харківського науково-дослідного інституту судових експертиз ім. засл. проф. М.С. Бокаріуса

СВДОКІМЕНКО Сергій Анатолійович - кандидат юридичних наук, доцент кафедри кримінально-правових дисциплін та адміністративного права Харківського університету
\end{abstract}

DOI:10.32782/EP.2020.2.11

Статья посвящена анализу общих и спеицальньхх мер предотвращения насильственнъих преступлений. Сбормулировано понятие названных мер и рассмотрена их специфика. Определенъ сферы интеграции даннъгх мер с одновременной разработкой предложений по совершенствованию отдельнъхх направлений оперативно-служебной деятельности правоохранительных органов.

Ключевъе слова: насильственное преступление, правоохранительнье органъ, предотвращение, противодействие, сотрудник.

Аюдина, іiі життя і здоров'я, честь і гідність, недоторканість і безпека визнаються в Україні найвищою соціальною цінністю (ст. 3 Конституції України). Питання забезпечення захисту прав людини і громадянина є пріоритетним у правовій державі. Відомо, що основним, базовим правом людей $є$ право саме на безпеку. Ця конституційна концепція $є$ вихідною, загальною, а тому повною мірою актуальною для теперішнього моменту, особливо з урахуванням того, що зараз, як ніколи, проблеми боротьби 3 протиправними проявами у суспільстві набули доленосного значення. У цих умовах правовий стандарт охорони людського життя, здоров'я і гідності потребує додаткових гарантій, бо їх життєдіяльність у цей конкретний історичний момент пов'язана з постійно наявним ризиком виникнення безпосередніх чи потенційних небезпек для їх життя та здоров'я. На цьому фоні значно ускладнюеться протидія, запобігання та профілактика криміногенних факторів, що зумовлюють насильство.

Настала гостра потреба вжиття дієвих заходів боротьби та запобігання насильницьким злочинам. Певні кроки щодо цього, які робляться 3 метою законодавчого врегулювання проблем боротьби із злочинністю, потребують належного наукового узагальнення й аналізу. Підкреслимо, що стан дослідження проблеми ще не відповідає вимогам сьогодення. Передусім відчувається гостра необхідність розробки нових, ефективних підходів до здійснення запобігання злочинам, завдяки чому можна досягти відчутних позитивних зрушень у подоланні тенденції зростання їх кількості. Враховуючи це, метою цієї статті є обгрунтування думки про те, що саме комплексний інтегративний підхід до формування системи запобіжних заходів є запорукою успіху у справі протидії насильницьким злочинам.

Загалом цій проблемі у кримінології приділена певна увага, зокрема у роботах Г.А. Аванесова, В.С. Батиргареєвої, E.О. Гладкової, В.В. Голіни, А.М. Давиденка, I.M. Даньшина, О.М. Джужи, А.Е. Жалинського, А.П. Закалюка, О.Г. Кальмана, О.М. Костенка, В.М. Кудрявцева, О.М. Аитвака, О.М. Аитвинова, Ф.А. Аопушанського, В.В. Аунєєва, О.Б. Сахарова, В.М. Соміна та деяких інших вчених, адже для науковців реалії життя дають багато фактів для аналізу й осмислення. Втім питання інтеграції форм і методів, а також засобів запобігання насильницьким злочинам так i залишилось поза 
увагою дослідників; натомість від них прямо залежить безпека всього населення нашої держави.

Підхід до насильницької злочинності як до соціально-негативного явища передбачає відповідну стратегію дій щодо запобігання злочинної поведінки. Система запобігання включає в себе діяльність спеціалістів з різних галузей знань: психології, педагогіки, права, спрямованих на запобігання можливим психологічним, соціокультурним та поведінковим відхиленням осіб, які належать до «груп ризику», збереження, підтримку і захист, нормального рівня життя та сприяння їм у досягненні поставлених цілей. Отже, запобігання насильницьким злочинам - це комплексна діяльність, яка має на меті усунення ймовірності вчинення злочину і виступає в декількох взаємозалежних аспектах:

- як засіб соціального регулювання найбільш значимих суспільних відносин;

- комплекс заходів правового, виховного, спеціально-кримінологічного характеpy;

- система різних рівнів запобігання і превенції злочинності, що лежить в основі діяльності різних суб’єктів.

Комплекс заходів із запобігання насильницьким злочинам повинен бути спрямований на вирішення наступних завдань:

- визначення індивідуальних факторів ризику і вжиття заходів, що змінюють злочинну поведінку особи;

- налагодження співпраці працівників правоохоронних органів з громадськістю та проведення профілактичних бесід серед осіб 3 девіантною поведінкою;

- систематичний аналіз оперативної обстановки в межах певних адміністративно-територіальних одиниць, проведення систематичних комплексних відпрацювань найбільш криміногенних ділянок місцевості, районів тощо із залученням різних сил та засобів правоохоронної діяльності;

- спостереження за особами, схильними до злочинної поведінки, з метою вчасного втручання та формування моральних стандартів поведінки, пропаганда здорового способу життя, розвиток системи цінностей, спрямованих на нейтралізацію різних девіантних форм поведінки особи;
- створення цивілізованої, соціально орієнтованої моделі контролю над супутніми (фоновими) явищами, що супроводжують насильницьку злочинність;

- розробка міжвідомчих програм або скоординованих планів погоджених дій різних суб’єктів щодо усунення причин на умов вчинення злочинів певної категорії.

Залежно від ієрархії причин та умов злочинності виділяють три основні рівні iï запобігання: загальносоціальний, спеціально-кримінологічний та індивідуальний [1, c. 159].

Загальносоціальне запобігання злочинності пов'язане 3 найбільш значущими видами соціальної діяльності, масштабними заходами щодо розвитку економіки, соціальної інфраструктури, управлінської сфери, підтримання культури й моральності, зміцнення конституційних засад законності стосовно забезпечення прав, свобод, законних інтересів громадян та їх соціального захисту. Такі заходи, як правило, розглядають як основу спеціальної профілактики, оскільки вони спрямовані на обмеження підгрунтя злочинності та протидію криміногенним факторам у суспільстві.

Основними напрямками загальносоціального запобігання злочинам будуть виступати три сфери: соціально-економічна, політико-правова і духовно-моральна [2, с. 294].

Насамперед, запобігання насильницьким злочинам - це комплекс перспективних соціально-економічних і культурно-виховних заходів, спрямованих на подальший розвиток та вдосконалення відносин між громадянами і усунення або нейтралізацію разом з тим причин та умов злочинності в цілому. Тому вирішальна роль у поступовому зменшенні соціальних суперечностей в усіх сферах соціального життя громадян належить розумній господарсько-організаційній та культурновиховній діяльності державних органів та громадських організацій. Запобіжний потенціал цієї діяльності полягає в тому, що вона протидіє негативним явищам і процесам, які сприяють відтворенню або збільшенню рівня злочинів, стимулює законослухняну поведінку людини. Вони не мають спеціальної мети боротьби зі злочинними проявами, але проведення їх у життя створює необхідні 


\section{Кримінальне право, кримінальний процес та криміналістика}

умови для попередження кримінально караних діянь [3, с. 102].

Соціальним адресатом загальносоціального запобігання насильницьким злочинам може бути як усе населення нашої держави, так і окремих регіонів чи місцевостей. Загальносоціальне запобігання насильницьким злочинам спрямоване на мобілізацію всіх членів суспільства для боротьби із такими явищами об'єктивної дійсності, які за певних умов створюють можливість переходу окремих осіб від загальноприйнятої до антигромадської позиції та поведінки. Загальносоціальне запобігання покликане забезпечити нормальну, тобто правомірну поведінку всіх членів суспільства, інакше кажучи це стримувальний від правопорушень вплив на всіх осіб, який має своїм джерелом соціальні, в тому числі правові норми, відповідну поведінку державних органів, громадських організацій та окремих осіб.

Отже, метою загальносоціального запобігання насильницьким злочинам є доведення до всіх членів суспільства правил та норм поведінки, роз'яснення, тлумачення наслідків вчинених правопорушень. Крім того, це позитивний ефект продуманої соціальної політики, яка здійснюється не тільки і не стільки 3 метою безпосереднього запобігання злочинності; воно спрямоване, перш за все, на вирішення економічних та соціальних завдань держави. Метою загальносоціального запобігання злочинності є також зменшення соціальних суперечностей, криміногенного протистояння різних верств населення, що сприяє побудові міцного фундаменту нормального функціонування всіх соціальних сфер, правового виховання дітей та молоді, оздоровлення морального клімату в суспільстві, впровадження високих моральних цінностей у ньому, додержання демократичних засад та інше. Прогресивні соціальні програми, спрямовані на утвердження законності, поваги до конституційних прав і свобод людини, зміцнення громадського порядку, дисципліни, на вирішення проблем поєднання громадських, виробничих, сімейно-побутових інтересів сім’і, соціальної адаптації маргінальних верств населення, є компонентами загальносоціального вектора запобіжної діяльності.
Із загальносоціальним запобіганням насильницьким злочинам тісно пов'язане спеціальне запобігання, під яким слід розуміти соціальний процес, основою якого 6 використання спеціальних методів і прийомів, знань та навичок регулювання соціальних відносин винятково з метою ліквідації тих їх негативних моментів, які можуть провокувати вчинення злочинів, тобто з метою забезпечення дотримання кримінально-правових вимог [4, с. 100]. Воно спрямоване на виявлення і усунення або послаблення дії факторів, що детермінують злочинність у цілому, окремі види і групи злочинів, причини та умови конкретних злочинів [5, с. 25-26].

Враховуючи стресові ситуації, 3 якими кожен день стикається людина, збільшення психічних відхилень, загальної девальвації моральних цінностей, наркотична та алкогольна епідемія, яка захопила населення, працівники правоохоронних органів зобов'язані бути максимально витриманими, рішучими, їх діяльність повинна бути гуманною як за формою, так і за суттю. Працівники повинні поєднувати професійні знання, навички та загальнокультурний потенціал.

Найважливішими заходами спеціальнокримінологічного запобігання є: втручання у кризові ситуації; зменшення практичних можливостей вчинення насильницьких злочинів; виховна та інформаційна робота серед населення; залучення громадськості до запобігання насильницьким злочинам; надання допомоги жертвам цих злочинів тощо.

3 метою запобігання насильницьким злочинам можуть здійснюватись заходи по створенню обстановки, яка виключала б можливість вчинення таких злочинів. До таких заходів належать:

- посилення охорони громадського порядку в межах певних адміністративно-територіальних одиниць або на певних об'єктах;

- виставлення додаткових (спеціальних) патрулів поліції або представників громадських формувань у місцях ймовірного вчинення злочинів;

- обладнання об’єктів засобами технічного контролю та спостереження, сигналізації тощо.

Загалом, якщо запобіжна сила кримінального закону, перш за все, в його мораль- 
ному і соціальному змісті, то цей статус закону автоматично ще більше підвищується, коли йдеться про боротьбу зі злочинними посяганнями на життя та здоров’я. Підвищена суспільна небезпека розглядуваних злочинів зумовлена не лише загальним рівнем небезпеки, але й емоційно загостреним станом суспільної думки щодо відвертого виклику злочинних структур суспільству, державі, іiі представникам. Отже, з метою забезпечення кримінологічної безпеки на даному рівні необхідно вирішити наступні завдання:

- виявлення намірів криміналітету протидіяти оперативно-службовим та службово-бойовим заходам, здійснювати насильницькі посягання;

- реалізація заходів з чинного фізичного та правового захисту різних категорій осіб, що сприяють здійсненню правоохоронної діяльності, та їх близьких від злочинних посягань;

- розкриття, розслідування насильницьких злочинів;

- попередження i припинення проникнення представників організованих злочинних груп, інших правопорушників та осіб, які мають орієнтації, що суперечать інтересам правоохоронної служби, в кадри, спецапарат та громадські помічники;

- недопущення прийому на службу осіб, які за своїми діловими, морально-вольовими характеристиками не відповідають вимогам здійснення правоохоронної діяльносTi;

- функціонування системи безперервної якісної професійної підготовки;

- виявлення, попередження, припинення протиправної діяльності окремих осіб, що займають штатні посади, позаштатних і негласних співробітників, а також громадських помічників, ангажованих криміналітетом або ініціативно здійснюючих службову та цивільну зраду, іншим чином зловживають службовим становищем;

- забезпечення збереження, припинення несанкціонованого доступу до секретної та іншої службової інформації, що характеризує правоохоронну діяльність;

- забезпечення конспірації в оперативно-розшуковій діяльності, збереження службової таємниці в адміністративно-юрисдик- ційній та профілактичній сферах, таємниці слідства - в процесуальній діяльності;

- забезпечення фізичної та технічної охорони приміщень, будівель, зброї, бойової, спеціальної та організаційної техніки, транспортних засобів, територій, що використовуються правоохоронними органами.

Отже, спеціально-кримінологічне запобігання органічно доповнює та конкретизує загальносоціальне, але ії заходи ухвалюються і здійснюються у розрізі окремих його складових і мають часові межі. Вони цілеспрямовані, спеціалізовані і так чи інакше локалізовані у часі та просторі щодо певних строків проведення, різних галузей господарства тощо.

Таким чином, на підставі аналізу загальносоціального та спеціально-кримінологічного запобігання насильницьким злочинам можна зробити наступні висновки:

1. Запобігання насильницькій злочинності як комплексна системна реакція суспільства на злочинні явища даного виду виступає в декількох взаємозалежних аспектах: як засіб соціального регулювання найбільш значимих суспільних відносин у правоохоронній сфері; комплекс заходів правового, виховного, спеціально-кримінологічного характеру впливу; система різних рівнів запобігання і припинення насильницької злочинності, що лежить в основі діяльності різних суб'єктів.

2. Загальносоціальні заходи запобігання злочинам - це сукупність економічних, політичних, ідеологічних, організаційних та інших заходів. Системність і специфіка запобіжних заходів на загальносоціальному рівні відносно насильницьких злочинів пов'язана 3 комплексними дослідженням таких груп проблем, як удосконалення ідеологічної та виховної роботи серед населення, зменшення соціальних суперечностей, мінімізація криміногенного протистояння різних верств населення, підвищення соціальних стандартів життя, що сприяє побудові міцного фундаменту для нормального функціонування всіх соціальних сфер, виховання та контролю над дітьми і молоддю, оздоровлення морального клімату в суспільстві, впровадження високих моральних цінностей у ньому тощо. 


\section{Кримінальне право, кримінальний процес та криміналістика}

АНОТАЦІЯ
Статтю присвячено аналізові загальних
та спечіальних заходів запобігання насиль-
ницьким злочинам. Сформульовано поняттл
названих заходів та розглянуто їх специбіку.
Окреслено сфери інтеграчї запобіжних захо-
дів з одночасним виробленням пропозицій з
удосконалення окремих напрямків діяльності
правоохоронних органів.
Ключові слова: насильницький злочин,
правоохоронні органи, запобігання, протидія,
працівник.

3. Спеціально-кримінологічне запобігання насильницьким злочинам спрямоване на виявлення і усунення або послаблення дії факторів, що детермінують злочинність у цілому, окремі види і групи злочинів, причини та умови конкретних злочинів. Найбільш оптимальними заходами $є$ : втручання у кризові ситуації; зменшення практичних можливостей вчинення насильницьких злочинів; виховна та інформаційна робота серед населення; залучення громадськості до запобігання насильницьким злочинам; надання допомоги жертвам цих злочинів тощо.

4. Загальносоціальне та спеціальнокримінологічне запобігання насильницьким злочинам взаємопов'язані і взаємодоповнюють одне одного.

\section{Аітература}

1. Кримінологія. Академічний курс / Кол. авторів ; за заг. ред. О. М. Аитвинова. К.: Видавничий дім «Кондор», 2018. - 588 с.

2. Кудрявцев В. Н. Стратегии борьбы с преступностью / В. Н. Кудрявцев. - 2-е изд. испр. и доп. - М. : Наука, 2005. - 352 с.

3. Гладкова Є.О. Питання загальносоціального запобігання злочинності. Вісник Кримінологічної асочіацій Украӥни : зб. наук. праць. 2014. № 7. C. 101-108.

4. Бандурка О.М., Аитвинов О.М. Поняття і зміст спеціально-кримінологічного запобігання злочинам. Вісник Кримінологічної асоизаціӥ Украйни: зб. наук. праць. 2016. № 2 (13). C. 98-108.

5. Алексеев А. И. Криминологическая профилактика: теория, опыт, проблемы : мо-

\section{SUMMARY}

The article is dedicated to analysis of the general and specific measures of prevention of violent crimes. It's stressed that the prevention of violent crimes as a complex system public reaction on this type of crime can acting in several interrelated aspects: as a means of social control of the most significant public relations in the law enforcement sphere; the complex of legal, educational, specially-criminological means; the system of various levels of prevention and suppression of violent crime, which conducted by different subjects.

The notion of these measures is formulated and their specificity is considered. Thus, the general social preventive measures - is an aggregate of economic, political, ideological, organizational and other measures. Systematic and specific of measures on the general social level for violent crime associated with the complex study of such groups of the problems as the improvement of ideological and educational work among the population, reduction of social contradictions, the minimization of criminal confrontation of different groups of the population, increase of social life standards that contributes to building a solid foundation for the normal functioning of all social spheres, education and control of children and young people, recovery the moral climate in society, the introduction of high moral values, etc.

But specially-criminological prevention of violent crimes is aimed at the revelation and elimination or weakening of the factors that determine criminality in general, separate species and groups of crimes, the causes and conditions of specific crimes. The most optimal measures are: intervention in crisis situations; decrease the feasibility of the violent crimes commission; educational and information work among the population; community involvement in the prevention of violent crimes; assistance to victims of these crimes, etc.

The sphere of the integration measures is defined and also given proposals for improving separate directions of operational activity of internal affairs agencies.

Keywords: violent crime, law enforcement agencies, prevention, counteraction, official.

нография / А. И. Алексеев, С. И. Герасимов, А. Я. Сухарев. - М.: Издательство НОРМА, 2001. - 496 c. 